\title{
A preliminary study of geographical names research: Review of cartography education \& research in Indonesia
}

\author{
Ari Cahyono $^{\mathrm{a}, \mathrm{b},} *$ Hartono $^{\mathrm{a}}$, Bowo Susilo ${ }^{\mathrm{a}}$, Niken Wirasanti ${ }^{\mathrm{c}}$ \\ ${ }^{a}$ Faculty of Geography Universitas Gadjah Mada, aricahyono@ugm.ac.id, hartono.geografi@ugm.ac.id, bowosusilo@ugm.ac.id \\ ${ }^{b}$ Doctoral Student on Geography, Faculty of Geography, Universitas Gadjah Mada \\ ${ }^{c}$ Faculty of Cultural Sciences Universitas Gadjah Mada,wirasarnti@ugm.ac.id \\ * Corresponding author
}

Keywords: Geographical names, cartographic education, Indonesia

\begin{abstract}
:
Geographical names research could be used to reveal the condition of the landscape. Many studies in the geographical names are arranged geographically, surveying geographical names in an area by compiling and analyzing historical spelling sequences to build the origin of etymological geographical names. The geographical names is inherent in human life from birth to death. The trend of geographical names research influenced by cartographic education. This paper aims to review cartographic education in Indonesia in order to reveal how geographical names research influenced by cartographic education.

We reviewed many universities that held cartographic, geography, and geospatial education. A paper of geographical names research and cartographic research in Indonesia also examined.

We concluded that cartographic education in Indonesia mixed in geography and geomatic study. The development of cartographic courses in universities influences the interest in geographical names study. Based on articles examined, the study of it in Indonesia is dominated by linguistics discipline. They used qualitative methods in their research. Though some of the articles based on the geographical perspective. On the other hand, the trend of geospatial research tends to the technological aspect rather than the concept of cartography. Thus geographical names research is rarely involved. However, with the implementation of geospatial information laws, One Map Policy, and government regulations regarding the geographical names would facilitate the rising of geographical names research. Several universities also opened a new study programme relate to the geospatial field.
\end{abstract}

